\title{
Cybersex as Affective Labour: Critical Interrogations of the Philippine ICT Framework and the Cybercrime Prevention Act of 2012
}

\author{
Elinor May Cruz and Trina Joyce Sajo
}

This chapter critically examines the underside of the Philippine Information Society-the cybersex phenomenon. In looking at cybersex, we take stock of the Philippine ICT framework's aim of building "a people-centered, inclusive, development-oriented Information Society" through the state promotion of Filipinos as "world-class" workers and citizens. We also look at how the Cybercrime Prevention Act of 2012 complements this state policy aspiration. We argue that the cybersex phenomenon illustrates how institutional development strategies propelled by ICT could inadvertently exclude already marginalized sectors of society. We use the perspective of affective labour to argue that because ICT-led development failed for these sectors, the response is an illegal service industry that also makes use of, if not feeds off, the same technological infrastructure largely supported by foreign capital. Cybersex is a potent example of how the marginalized learn to transform conditions of exclusion and illegality into creative, practical, and thus, productive strategies of survival. Cybersex is not the solution to achieving a decent quality of life, but the existence and persistence of this phenomenon signifies that the State's vision of ICT for development is not living up to its promise of socioeconomic upliftment. Through the institutionalized uses of technology, a culture of creative ICT use is constrained rather than promoted. Cybersex thus foregrounds some problematic ramifications of the present ICT framework and the institutional mechanisms supporting it. It puts to question the goal of inclusive development in Philippine ICT policymaking and legislation, hinting at the risks and repercussions of creating an "Information Society" under the neoliberal market

E.M. Cruz (凶)

Third World Studies Center, University of the Philippines-Diliman, Quezon City, Philippines e-mail: elinor.may.cruz@gmail.com

T.J. Sajo

University of Western Ontario, London, ON, Canada

e-mail: trinajoyce.sajo@gmail.com 
economy. Addressing this challenge, we propose, begins with a reconsideration of cybersex as a form of ICT-facilitated affective labour and learning from the multifaceted narratives that constitute informal uses of ICTs.

\section{Introduction}

This chapter looks at the cybersex phenomenon in the Philippines amidst government efforts to promote "ICT for development" (ICTD). Embedded in the purported cybersex capital of the world, the cybersex phenomenon in the Philippines begs for a critical reflection on the implications of ICT-led national growth, especially for those at the margins of techno-social development. The absence of studies in the cybersex phenomenon is glaring, much less in the backdrop of ICTD, and this chapter's work in the Philippine context makes a modest contribution in filling this research gap.

Attempts to grapple with the role of technology in this so-called online version of prostitution have been undertaken through bills filed in the Philippine legislature. In September 2012, the Benigno S. Aquino III administration enacted the omnibus Cybercrime Prevention Act of 2012, which casts cybersex as a cybercrime. ${ }^{1}$ Propped up by the Aquino administration's ICT framework also known as the "Philippine Digital Strategy" (PDS), the law promulgates that cybersex, among other cybercrimes, should be prevented to safeguard and promote the integrity of the country's burgeoning ICT industry. Within the purview of the ICT framework and the Cybercrime Law, cybersex serves as a threat to the state project of a "Philippine Information Society." In this chapter, we re-examine the Philippine ICT framework and the Cybercrime Law and how these official discourses impinge on what may be considered as the underside of the Philippine Information Society. In labelling cybersex as a crime, we, the authors, believe that the existing ICT framework and the Cybercrime Law address only the symptoms and not the causes of this phenomenon.

In looking at cybersex, we unpack the Philippine ICT framework's aim towards "a people-centered, inclusive, development-oriented Information Society" (PDS 2010) and how the Cybercrime Law serves this aim. We argue that the cybersex phenomenon in the Philippines illustrates how state developmental strategies propelled by ICT could inadvertently exclude, even alienate, sectors of society for whom development outcomes promise to have an import. Perhaps because ICTled development failed for these sectors, the response is an illegal service industry that also makes use of, if not feeds off, the same technological infrastructure largely supported by foreign capital. We hinge our arguments on an alternative conceptual

\footnotetext{
${ }^{1}$ The cybersex provision of the law defines cybersex as: "The willful engagement, maintenance, control, or operations, directly or indirectly, of any lascivious exhibition of sexual organs or sexual activity, with the aid of a computer system, for favor or consideration" (Cybercrime Prevention Act of 2012). The law, placed on an indefinite restraining order due to challenges against its constitutionality (Romero 2013), was declared constitutional by the Philippine Supreme Court in February 2014.
} 
understanding of cybersex through the lens of "affective labour," to argue that the excluded members of society learn to transform the conditions of exclusion and illegality into creative, practical, and thus, meaningful and productive strategies of survival. In view of the above, the key question that comes to our mind is this: does casting cybersex as a cybercrime, "(threatening) the moral fibres of our society," lead to a truly inclusive Philippine Information Society? ${ }^{2}$

This chapter begins with a sketch of the Philippine ICT framework motivated by the State's vision of an ICT-led development, particularly through the Philippine branding of "world-class" cyberservice provision. We then zoom in on the underside of the Philippine Information Society, to begin problematizing the cybersex phenomenon in the context of a digital sexual economy. Next, we give a discussion on the relevant conceptualizations of affect in providing the theoretical foundation in our undertaking to view cybersex as affective labour. This is followed by arguments to use affective labour as an alternative perspective to give emphasis on the lived experiences of individuals engaged in cybersex, as well as their agency through the use of ICT. Finally, we offer a critical re-examination of the Philippine ICT framework and the Cybercrime Law and their implications for ICT for development. We wrap up the chapter with some concluding thoughts.

\section{The Philippine ICT Framework: Exclusions from an Inclusive Growth}

In 2006, the Gloria Macapagal-Arroyo administration laid down the Philippine ICT roadmap (CICT 2006), signifying the government's abiding faith in ICTs as an engine of development. The roadmap, created by the Commission on Information and Communications Technology (CICT) under the Office of the President, served as the government's blueprint for creating what it called "a people-centered, inclusive and development-oriented Information Society" (PDS 2010). Strategies in the roadmap included universal access to ICT, developing human capital, efficiency and transparency in governance through ICT, competitiveness in the global ICT economy and crafting an ICT policy framework.

Pushing for ICT-led national growth meant the Philippine government banking on the country's competitiveness as the top provider of cyberservices in the new economy. The Philippines has been branded as a "Cyberservices Corridor"a 600-mile spectrum of ICT-enabled services, boasting of nothing less than "quality, innovation and world-class sophistication" (CICT 2006). To ensure that worldclass service is developed and sustained, the roadmap highlights its "workforce mobilization programme" to enhance English competency and provide industry

\footnotetext{
${ }^{2}$ See Castillo (2010) on Carmelo Lazatin's statement. Lazatin is author of House Bill 1444, also known as the "Anti-Cybersex Act." This bill would go on to constitute, among others, the Cybercrime Prevention Act of 2012.
} 
certification and career advocacy — ensuring a steady supply of "twenty first century knowledge workers" (CICT 2006). Alongside workforce development, the roadmap proposed policy reforms on the safety and reliability of the technological infrastructure to boost confidence in the country's ICT industry. By the end of the Arroyo administration, revenues for the ICT service sector grew sevenfold and employment was five times more than the 2004 baseline figures (PDS 2010)—giving credence to government claims of the benefits of ICT-led national growth: "(G)reater investment flows, more jobs, a better quality of life for the populace" (CICT 2006).

It is not surprising that the Philippine Digital Strategy under the Aquino administration endeavoured to maintain the country's top position in cyberservice provision. The Philippine ICT industry, particularly the Information Technology and Business Process Outsourcing (IT - BPO) sector, contributes almost $5 \%$ of the country's GDP and employs over half a million full-time employees (PDS 2010). Hence, strategies in the PDS also included developing a more coherent national brand, ${ }^{3}$ identifying Next Wave Cities ${ }^{4}$ for the Philippine Cyberservices Corridor and setting into high gear the "development of world-class knowledge workers and the promotion of a culture of creative ICT use" (PDS 2010).

Further pushing the country's global competitiveness through its "ICT for governance" frame, the PDS implemented security measures for the country's business and technological infrastructure. The Cybercrime Prevention Act of 2012 manifests state intent to combat cybercrime in recognition of the ICT industry's role in the country's socioeconomic development. Cybercrime, as stipulated in the law, constitutes (1) offences against the confidentiality, integrity and availability of computer systems, such as system interference and cybersquatting; (2) computerrelated offences, such as computer-related forgery, computer-related fraud and computer-related identity theft and (3) content-related offences, such as cybersex and child pornography (Cybercrime Prevention Act of 2012). While the previous administration aimed to develop "a vibrant, accessible and world-class ICT sector" in sustaining global competitiveness (CICT 2006: p. 2), the current dispensation did this and more-it assured ICT-related businesses the secure environment conducive to their steady expansion (PDS 2010). As a result, the country's ranking on "ease of doing business" in industry and service sectors moved up ten notches since 2010 in the 2012 World Bank International Finance Corporation report (NSCB 2012).

Constituting the collective of cyberservice providers are Filipinos employed as hardware and software developers, web designers and "technopreneurs" (SalomaAkpedonu 2006: p. 2) and call centre agents, such as technical support specialists and customer service representatives. The PDS (2010), however, in promoting the

\footnotetext{
${ }^{3}$ The PDS (2010) states that the Aquino government plans to streamline its national branding efforts with marketing campaigns of its Southeast Asian neighbours, as in the case of Malaysia"Malaysia, Truly Asia" for tourism and "Malaysia, Truly Business" for outsourcing.

${ }^{4}$ Defined in the PDS (2010) as "a Philippine-specific term that identifies ICT hubs beyond Manila, based on criteria such as worker supply, telecom infrastructure and other factors necessary to sustain a local BPO industry".
} 
"Philippine brand of cyberservice provision" refers to their communicative, "soft" skills and personable traits rather than their technical competencies:

English language proficiency, adaptability, educated, a deep-seated value system that prizes serving others, commitment and loyalty, cultural adaptability, and familiarity with Western business culture... (poise Filipinos) to becoming members of the next-generation of highly-valued and fully effective 21 st century workers and citizens. (PDS 2010)

The premium placed on these traits led to investments in English proficiency and basic ICT skills training (Diaz de Rivera 2008) that go hand in hand with the Philippine brand of cyberservice provision. ${ }^{5}$ This mode of branding Filipino labour is exemplified in call centre work. Labour of this type entails "the simultaneous (overlapping) delivery of physical labour (e.g., use of hardware and software technology); mental labour (e.g., English competency and juggling time zones); and emotional labour (e.g., customer service and developing an American accent)." (Saloma-Akpedonu 2006: p. 50). What binds these forms of "immaterial labour" is "the affective labour of human contact and interaction" (Hardt 1999), with the affective qualities of cyberservice provision proving attractive to the international labour market. The Philippines has been consistently the destination of choice of most IT-BPO businesses, producing USD 8.91 billion in revenues in 2010 alone (PDS 2010). ${ }^{6}$ In the news, Information Technology and Business Process Association of the Philippines (ITBPAP) Senior Executive Director Gillian Virata lauds the unique traits of the Philippine workforce, that ensure the country remains "the destination of choice for customer-relations management":

The primary driver (of the industry) is the world-beating performance... unique to the Philippine work force... we are pleasant to work with. We are also easy to train... we are easy to understand; we understand foreigners; and we empathize. (Estopace 2013)

In the 2013 survey of top global outsourcing destinations, Manila outranked New Delhi, placing third before Bangalore and Mumbai (GMA News 2013a). ${ }^{7}$ In its race with India as the call centre capital of the world, the Philippines' sunshine industry is considered the country's "new eternal sunshine" or "perennial growth machine", running parallel to revenue contributions of overseas employment (Estopace 2013). ${ }^{8}$

In putting the ICT industry at the helm of economic growth, however, the question remains whether the increase in jobs and growth has actually led to a "better quality of life for the populace" (CICT 2006). Despite the National Statistical

\footnotetext{
${ }^{5}$ It is a common sight in urban communities to display tarpaulin posters of local politicians promoting call centre training as one of the local government's livelihood programmes.

${ }^{6}$ The PDS (2010) boasts of the country's global leadership in voice services in the IT-BPO sector.

${ }^{7}$ The online report may be found here: http://www.cuti.org.uy/documentos/Tholons_Top_ 100_Ranking_2013.pdf

${ }^{8}$ The ranking report also highlighted the country's efforts not just to maintain its leadership in voice services but also in expanding to other sectors in outsourcing and even going beyond US markets (GMA News 2013a).
} 
Coordination Board (NSCB) reporting a substantial increase in Internet access in the country (Remo 2013) — an increase that positively impacts a country's digital economy ranking - the NSCB also reports that the country's economic situation leaves much to be desired. In the 2013 Philippine Statistics in Brief, the NSCB (2013) reported that first semester figures for the proportion of poor Filipino families including those living under extreme poverty in 2006, 2009 and 2012 have not changed. ${ }^{9}$

\section{Cybersex Capital of the World: Treading the Underside of the Emerging Philippine Information Society}

The achievements of the Philippine ICT industry, especially the IT-BPO sector, according to Budget Secretary Florencio Abad, have "put a face to our aspirations for the economy" (GMA News 2013b). The IT-BPO sector had USD 11 billion revenues in 2011 and USD 13 billion in 2012, even stimulating growth in related industries, from telecommunications to food and beverage services (GMA News 2013 b). The IT-BPO sector reportedly projected revenue worth USD 16 billion for 2013 (GMA News 2013b) and the ITBPAP is reportedly targeting revenues worth USD 25 billion for 2016 as well as 1.3 million jobs in the country (GMA News 2013c). Yet, incidental to the country's rip-roaring growth industry is the emergence of a shadow economy as its "sordid side effect" (Cordova 2011). Sprawling all over the country, the cybersex phenomenon adds yet another moniker to the Philippines as cybersex capital of the world.

In November 2013, Terre Des Hommes Netherlands, a Dutch NGO working against "webcam child sex tourism", simulated Sweetie a 10-year-old Filipina, to lure predatory individuals on the hunt for children from poor countries to perform sex acts online (Quigley 2013). While the Aquino government reportedly planned to question the NGO's choice to depict "Sweetie" as Filipina (Fabunan 2013), the group was actually able to snare 20,000 alleged predators exposing the contradiction of competing images the Philippines is beset with (Quigley 2013). Sweetie as the face of cybersex outlines the contours of what may be inferred as the ICT industry's digital sexual economy.

\subsection{The Digital Sexual Economy}

Cybersex, in the case of the Philippines, sprung from the text-heavy online community platforms such as My Internet Relay Chat (mIRC) and Yahoo! Chatrooms, where chat members have sex via sex eyeball (SEBs), sex on phone (SOPs), or with

\footnotetext{
${ }^{9}$ See NSCB press release here: http://www.nscb.gov.ph/poverty/defaultnew.asp/
} 
the use of web cameras (Sabangan 2003). ${ }^{10}$ Advocates of the liberatory potential of the Internet, through such prosumer practices may be quick to point to the challenges these practices pose against, if not lead to the effacement of power structures and relations. But this is not often the case, because in a racialized and sexualized digital economy, the Filipino user's body carries an exchange value. Key words most commonly used in these chatrooms, such as Pinay pussy, Asian tranny, etc., are examples of commodified content, that reveal the racialized and sexualized nature of "supply and demand" in these online activities. As the Internet serves as an open market for goods and services, these online content and activities have come to generate value for profit for "e-capitalists" (Cote and Pybus 2007) - the most popular example would be the circulation of the commodified, exoticized image of a sexy and subservient Filipina online.

Moreover, multinational companies that provide Internet-related products and services, such as Google, commodify user content and activities or turn them into information goods or services to be sold, for instance, to third-party vendors (Robins and Webster 1988; Carr 2010). Online activities, including sexual content, are thus forms of immaterial labour, quantified and made profitable for Internet businesses (Lazzarato 1996; Cote and Pybus 2007; Dowling et al. 2007). Cybersex, reinvented in multimedia platforms, is now made available in live sex video chat websites, equipped with sophisticated and secure modes of online payment transactions. Such online content and activities now meant creating value for profit, alongside the rapid creation and expansion of business and technological infrastructures to run the digital sexual economy.

In looking at the cybersex phenomenon in the context of a digital sexual economy, we critically rethink the so-called revolutionary nature of ICTs. Examining Filipinas depicted online exclusively as mail-order brides, sex workers, and maids, Gonzalez and Rodriguez argue that ICTs "exacerbate intra-Asian and imperialistic histories of exploitation in the present, creating a specificity of experience that begs for a critical rethinking of the Internet as revolutionary technology" (2003: p. 16). They also contend that pornographic, dating, and marriage websites can be inferred to as "(the circulation of) Filipinas in ways reminiscent of colonial and global histories" (Gonzalez and Rodriguez 2003: p. 217). The simulation of Filipino sex-bot Sweetie is thus indicative of the racialized digital sexual economy and the symbolic violence that accompanies the circulation of Filipino bodies online. This resonates with the observations of ICT scholars examining the digital sexual economy. ICTs appear to facilitate the development

\footnotetext{
${ }^{10}$ In Annie Ruth C. Sabangan's (2003) first of a five-part special report on cybersex titled "In the chatrooms: A look into the minds of cybersex addicts", she defines sex eyeball as "when you get tired of CS [cybersex] and long for the real thing. When your chatmate is ready for SEB, you exchange cell phone numbers, plan where and when you will meet to have the "big S"'. She also defines sex on phone as: "Elevate your verbal CS to auditory CS. Grab the phone, hear each other's moans, while your other hand is busy exploring your body's erogenous zones".
} 
of online sex tourism as a niche market in global tourism (Chow-White 2006), and even function "as an advertising medium for world sex" (Nagel 2003).

While we do acknowledge the exploitative elements of cybersex, we do not want to treat it merely as an issue of gender and sexual exploitation. Such a priori understandings of cybersex could impede productive and meaningful outcomes in research. Cybersex should be seen as mediated by technology, and couched in the networks of digital capitalism which subsume the digital sexual economy. We learned from Ditmore's study of Calcutta sex workers the importance of treating prostitution and trafficking-related abuses as labour issues to advance sex workers' protection. We also recognize a cybersex worker's claim that cybersex resembles call centre work (The Vincenton Post 2009), assimilating other forms of labouremotional, cognitive, communicative, and technical-opening up the cybersex phenomenon to different alternative readings. Positing cybersex as affective labour, therefore, means that cybersex needs to be understood within these overlapping discourses.

\section{On Affect: A Prelude to Cybersex as Affective Labour}

The utility of affect is significant for its theoretical and practical reconsideration of the neoliberal subject (Paasonen 2011), giving expression to "a new configuration of bodies, technology, and matter" (Clough and Halley 2007: p. 2). Central to theoretical perspectives on affect is "the capacity to affect and to be affected", which stems from Dutch philosopher Baruch Spinoza's philosophy of ethics (Clough and Halley 2007; Clough 2010). This is the underlying logic that compels the moment preceding emotions and psychological states towards movement and action. Affect is not limited to feeling states; it encompasses forms of energies and forces that emanate from the body (Brennan 2004), as well as the body's potentiality, capacities and consequences (Clough et al. 2007; Clough 2010).

Approaches to affect are related but differ in their emphases and concerns (Seigworth and Gregg 2010), and we draw on three of these iterations. The first approach, drawing on thermodynamics, cybernetics and information theory, construes the individual as an organism whose affective capacities enable not only rational thought and action (Clough and Halley 2007) but also irrational, sometimes inconsequential states. Affect is a reservoir of potential matter and energy for determined and unintended actions, and often emerge as intensities (Hayles 1999; Hansen 2006; Massumi 2002; Clough and Halley 2007; Clough 2010; Gregg and Seigworth 2010). It also carries political possibilities or individual capacities for selforganization-what may be referred to as "autopoiesis" (Massumi 2002; Clough and Halley 2007). However, in an era of "intensified financialization", the productivity of affect is a constant struggle between its autonomy and commodification (Clough 2010: p. 219), bound up with forms of neoliberal biopolitics and the regulation of populations. Biopolitics here is defined as "the extension of an economic rationality to all aspects of society, including life-itself" (Clough et al. 2007: p. 72). 
The second approach to affect pertains to the reproduction of "affective" responses to risk and uncertainty with the rise of financialization and the role of affective labour to assuage such conditions (Betancourt 2010). Digital capitalism induces and sustains "the illusion of a self-productive domain, infinite, capable of creating value without expenditure, unlike the reality of limited resources, time, expense and so on, that otherwise govern all forms of value and production" (Betancourt 2006). This simulates the "production and maintenance of ignorance" in the realms of consumption and labour (Betancourt 2010). In other words, ICT industries tap on the mental and emotional states of its users' mental and emotional states to keep the Internet economy going, especially its business infrastructure, and to ensure that insidious schemes of capitalist profit extraction remain hidden.

A third view of affect references affective labour as a subset of immaterial labour. The latter denotes forms of linguistic, communicative and knowledge work that have gained prominence in the era of post-industrial, neoliberal capitalism (Hardt and Negri 2000). Affective labour is "immaterial, even if it is corporeal and affective, in the sense that the products are intangible" (Hardt 1999: p. 96). Affect assimilates cognitive elements, and more importantly, modulates other people's affects and one's own:

Unlike emotions, which are mental phenomena, affects refer equally to body and mind. In fact, affects, such as joy and sadness, reveal the present state of life in the entire organism, expressing a certain state of the body along with a certain mode of thinking. Affective labour, then, is labour that produces or manipulates affects. (Hardt and Negri 2004: p. 108)

Affect is a highly valuable commodity and affective labour's propensity to modulate the former becomes the latter's ultimate advantage. Unlike Patricia Clough's (2010) definition of biopolitics, which suggests a top-bottom or systemsbased generation of power, biopolitics comes from the work of labourers producing all sorts of affects (Hardt 1999; Negri and Hardt 1999). The biopolitical power of affective labour is thus double-edged: on the one hand, it is highly valuable for capitalism to generate profits; on the other, it creates an advantage for the labourer because it can be reproduced indefinitely and "beyond measure" (Negri and Hardt 1999)_affective labour as "immaterial" commodity also makes it easy to evade control or surveillance. Ultimately, in this third approach, affective labour is the crucial game-changer for capitalism (Hardt 1999; Negri and Hardt 1999).

\section{More Than One Side to the Story: Understanding Cybersex as Affective Labour}

News headlines banner the proliferation of cybersex dens in the Philippines, where children and women have been trafficked into what mainstream media calls "modern form of slavery" (Lopez 2013). The prevailing narrative which tends to pigeonhole cybersex into one type of experience and excludes other possible experiences, is only one side of the story. Clearly, there are cybersex accounts that speak of the "oppression paradigm" (Weitzer 2010), where children and women 
fall prey to exploitative operators. The alternative view contends that, more often than not, considering sexual commerce as a form of harm potentially places sex workers in more danger becuase of stigma and discrimination and the lack of protection measures (Ditmore 2007). The very discourse of exploitation can serve as a self-fulfilling prophecy. It adds to the oppression of those who engage in cybersex, instead of recognizing their strategies of survival and self-improvement. The exploitation discourse obscures the enabling aspects and practical benefits of cybersex as a specific form of ICT use in everyday life. The moral binaries with which the State has cast cybersex-legal versus illegal, moral versus immoralevade the serious ramifications stemming from state efforts to promote ICT for development. How should the state make sense of Internet users engaged in cybersex work if they stand to benefit from it, including their families? What about the instrumental value of cybersex work in situations where quality education and sustainable livelihood are either lacking, ill-suited, or ineffective? In promoting the integrity of the country's business environment and suppressing cybercrimes, whose interest does the Cybercrime Prevention Law protect? What does cybersex tell us about the risks and repercussions in the creation of an Information Society under a neoliberal digital economy?

In viewing cybersex as affective labour, we see the potential of challenging State efforts in building a Philippine Information Society and problematizing the consequences of how the State reproduces modes of affect in the new economy through branding the information technology labor economy as "world class service." Through its ICT framework, the State has inadvertently set the stage where cybersex workers have come to modulate the affects of other individuals and their own and immediately pass judgement on this "sexually explicit" service provision. Cybersex as affective labour thus compels us to critically look at these overlapping spheres institutions and mechanisms that benefit from and allow certain received understandings to be produced, institutionalized and maintained. This pespective makes possible alternative understandings, especially one that brings us back to the cybersex workers, the "bodily bearers" of this phenomenon. ${ }^{11}$ This framework emphasizes the experiences of the worker and the work ${ }^{12}$ they do through strategies of accommodation, negotiation and resistance in highly precarious conditions.

The affective labour perspective emphasizes agency as much as victimization, without reducing the practice and outcomes of cybersex to one or the other. The cybersex worker may be placed under oppressive conditions, such as exploitative

\footnotetext{
${ }^{11}$ See Tadiar's (2009) argument of Filipina women as "bodily bearers" of sexual economies in the New World Order.

${ }^{12}$ While labelling cybersex workers "labourer" may suggest a structured labour and wage system typical of industrial and manufacturing workshops and factories, we use "labour" and "labourer" to emphasize the mobilization of affects as central to cybersex but use them interchangeably with the terms "work" and "workers".
} 
labor dynamics. At the same time, the worker's affective capacities generate values not just for capitalism but for herself, her family and even her community. ${ }^{13}$

Finally, cybersex differs from other forms of sex work because technology plays a key role in these activities. The role of ICT and the simultaneous material and immaterial elements at work require taking into account the distinctiveness of this type of mediated communication. Simply labelling it as prostitution or pornography or framing it narrowly as a moral issue prevents us from considering the broader contexts to understand why cybersex has developed and proliferated in the first place.

\section{Re-examining the Philippine ICT Framework and the Cybercrime Prevention Act of 2012: Implications ICT for Development}

The Philippine ICT framework programmed the country's ICT industry for the provision of the Filipino brand of "world-class service." It capitalized on the country's "human resource advantage" (CICT 2006) to strategically position the country in the global digital economy. The framework, we argue, inherently lacked enabling requisites for workers and citizens. Instead, it framed the role of the Filipino ICT labourer primarily as service and support, as exemplified by the provision of customer care, customer service or customer-relations management.

In reducing its workforce to front-liners in service provision, the government is pre-empting, rather than channelling, skills and energies toward the creative and meaningful strategies of ICT use. Pushing the country to be a leader in cyberservices destination, the State has exploited foreign capital and technology to rationalize and streamline labor. Affective labour, i.e. the mobilization of affect in cyberservice provision, becomes the product being sold in the global digital economy.

As the State endeavours to leapfrog ICT-led national growth, it excluded sectors it was quick to judge as illegal to sustain the integrity of ICT-related businesses and clear the ground for foreign investors. Thus, the State's limited understanding of cybersex and a priori judgement of cybersex workers has the tendency to be exclusionist. Categorizing cybersex as a crime has been a clear example of this. Understandably, determining which ICT practices are considered acceptable and legitimate, and justifying them based on perceived public threats, is a function of governance. With this approach, the State fails to consider values created from the periphery. ICT governance, preoccupied with creating limits and securitizing the technological infrastructure, unwittingly forces individuals and communities, especially those from the informal sector with little to no income or property, to live in subsistence and to rely on their means of survival. At worst, these people

\footnotetext{
${ }^{13}$ In a separate article, we delve into the lived experiences of cybersex workers, as well as business owners (Cruz and Sajo, forthcoming).
} 
find themselves in the hands of exploitative operators and the cycle of alienation continues. Through institutionalized or formal uses of technology, as articulated and operationalized by public-private partnerships and more so by the State, a culture of creative ICT use is constrained.

The emergence of cybersex could therefore be read as a symptom of the ineffectiveness of ICT-driven development. Cybersex, we argue, is a counterresponse to the inherent weaknesses in the State's programmatic approach towards developing the Philippine Information Society. Rather than allowing creative and practical uses of ICT among users, the State chooses to uphold its commitment to ICT-related businesses by giving a higher degree of penalty to crimes found in the Philippine Revised Penal Code when committed through ICT. If it is not working for the marginalized at best, then whose interests does the whole ICT infrastructure serve?

In casting cybersex as cybercrime, the State seems to evade the more fundamental problem of social exclusion that has brought about the informal economy of cybersex in the first place. Creating cybersex as a moral threat to the integrity of the Philippine Information Society obscures the fundamental problem of ICT development: the gap between formalized and informal ICT use to address the practical needs of the excluded for autonomy and self-improvement. Cybersex thus foregrounds the ethical dilemma of the present ICT framework and the institutional mechanisms maintaining it.

\section{Concluding Remarks}

In problematizing the cybersex phenomenon, we outlined the contours of the digital sexual economy in the ICT industry and laid down the theoretical foundation to foreground an alternative understanding of cybersex as affective labour. We offered to broaden the dominant perspective by using an alternative framework and pinpointing the many aspects of cybersex work. We argued that the State's project of ICT-led growth failed to impact on the quality of life of those living in the margins of techno-social development, and as a result, they resorted to cybersex, a creative, entrepreneurial, but morally questionable type of ICT use. Yet these efforts to eke out of poverty are shut down yet again, with the implementation of cybercrime legislation.

We believe that a meaningful ICT framework should aim to uplift the potential of Filipinos by recognizing and enhancing capacities for self-reliance, broadening life choices and chances to reduce socioeconomic inequity, and improving the quality of life especially for the deprived sectors of society. An effective ICT framework and its implementation cannot exclude or simply cast a moral frown on illegal ICT practices and those who engage in them. 
A first step towards this goal would be to learn from lived experiences of ICT users in thinking about harnessing ICTs to develop spaces of autonomy, information use, and personal development, while respecting privacy. If the state intends to build "a people-centered, inclusive, development-oriented Information Society", its ICT framework should not exclude cybersex workers and their affective labour, which includes utilizing English language competency, ICT skills, and the (sexualized) mode of "world-class" service. The affective labourer could manipulate consumer fantasies and desires and create strategies of resistance and negotiation in cybersex work. Inadvertently, cybersex creates opportunities for the development of workers' agency and strategies of economic survival strategies. The State should take into account the creative uses of ICT that are practical and meaningful to cybersex workers, and more importantly how they have come to regard these practices as such.

In light of the manifold ways ICT is used, the cybersex worker's capacity to not only be affected but to affect the creation of monetary and non-monetary values could potentially serve as meaningful information for designing more inclusive policies and institutional mechanisms in achieving socioeconomic development. Clearly, cybersex is not the solution to achieving a decent quality of life, but its existence and persistence signifies that the State's vision of ICT for development is not living up to its promise. But if the response, as it were, is to create more legal enclosures, i.e. cybercrime criminalization, we are doubtful whether this is an effective and responsive strategy for improving the quality of life of the marginalized, which can be argued as the root of the State's cybersex problem.

Examining cybersex in terms of affective labour and using this exercise to critique the Philippine ICT discourse have placed us in an uncomfortable position of confronting the complex ethical issues that cybersex engendered. The State's moral approach to cybersex is a means to preserve the integrity and viability of the country's ICT industries or the State's vision of a "Philippine Information Society." As the State takes strides be a leader in the global digital economy, it has marked Filipino ICT workers en masse as cyberservice providers, along with the proprietary "world class service" seal.

We argued that in rendering cybersex work illegal and immoral, the State has chosen to institutionalize the provision of service instead of recognizing the informal yet productive means by which cybersex workers attempt to make a living. Cybersex might just be the necessary threat to the pursuit of ICT-driven development to compel the State to recognize that Filipino ICT workers are much more than pawns for capital.

In the absence of a grounded understanding of the lived experiences of those engaged in this rampant and illicit phenomenon, we wonder whether cybersex even needs to be legislated. Cybersex demands complicating and superseding the dominant view that construes it as moral transgression, as preying on victims, as a criminal activity. How do we make sense of cybersex that eventually turns into a meaningful sexual relationship? How do we respectfully respond to cybersex workers who are using cybersex to provide for their economic needs and those 
of their families? Would it even be fair and ethical to point cybersex workers to more socially accepted ICT work such as call center work, knowing that this form of cheap, outsourced labor is also subject to new forms of surveillance and servitude (Mirchandani 2012)? It remains a challenge for Philippine ICT policy to address fundamental issues regarding genuine inclusive development. Responding to this challenge requires developing an ICT framework that starts from an empathic consideration of the grounded, multifaceted narratives and strategies on technology use and adaptation coming from marginalized individuals and communities.

Open Access This chapter is distributed under the terms of the Creative Commons Attribution Noncommercial License, which permits any noncommercial use, distribution, and reproduction in any medium, provided the original author(s) and source are credited.

\section{References}

Arviddson, A. (2007). Netporn: The work of fantasy in the information society. In K. Jacobs, M. Janssen, \& M. Pasquinelli (Eds.), C'lick me: A netporn studies reader (pp. 69-78). Amsterdam: Institute of Network Cultures. http://www.networkcultures.org/_uploads/24.pdf. Accessed 30 Nov 2013.

Betancourt, M. (2006). The aura of the digital. CTheory.net. http://www.ctheory.net/articles.aspx? id=519. Accessed 30 Nov 2013.

Betancourt, M. (2010). Immaterial value and scarcity in digital capitalism. CTheory.net. http:// www.ctheory.net/articles.aspx?id=652. Accessed 30 Nov 2013.

Brennan, T. (2004). The transmission of affect. Ithaca: Cornell University Press.

Carr, N. (2010). The shallows: What the internet is doing to our brains. New York: W.W. Norton \& Company.

Castillo, L. (2010). Solon seeks to prohibit cybersex operations in the country. http://www. congress.gov.ph/press/details.php?pressid=4703. Accessed 30 Nov 2013.

Chow-White, P. A. (2006). Race, gender and sex on the net: Semantic networks of selling and storytelling sex tourism. Media, Culture and Society, 28(6), 883-905. doi:10.1177/ 0163443706068922.

Clough, P., \& Halley, J. (2007). The affective turn: Theorizing the social. Durham: Duke University Press, 2007.

Clough, P. T. (2010). The affective turn: Political economy, biomedia, and bodies. In M. Gregg \& G. J. Seigworth (Eds.), The affect theory reader (pp. 206-225). Durham/London: Duke University Press.

Clough, P. T., Goldberg, G., Schiff, R., Weeks, A., \& Willse, C. (2007). Notes towards a theory of affect-itself. Ephemera: Theory and Politics in Organization, 7(1), 60-77.

Commission on ICT. (2006). Philippine ICT road map. http://www.unapcict.org/ecohub/resources/ philippine-ict-roadmap. Accessed 30 Nov 2013.

Cordova, J. (2011). Cybersex dens: A sordid side effect of the call center boom. http:// asiancorrespondent.com/45961/cybersex-a-sordid-side-effect-of-the-call-center-boom-inphilippines/. Accessed 30 Nov 2013.

Coté, M., \& Pybus, J. (2007). Learning to immaterial labour 2.0: MySpace and social networks. Ephemera: Theory and Politics in Organization, 7(1), 88-106.

Cybercrime Prevention Act of 2012. (2012). Retrieved from Official Gazette. http://www.gov.ph/ 2012/09/12/republic-act-no-10175. Accessed 30 Nov 2013.

Diaz de Rivera, A. T. M. (2008). Digital libraries and the Philippines' strategic roadmap for the ICT sector. Journal of Philippine Librarianship, 28(1), 55-77. 
Ditmore, M. (2007). In Calcutta, sex workers organize. In P. T. Clough \& J. Halley (Eds.), The affective turn: Theorizing the social (pp. 170-186). Chapel Hill: Duke University Press.

Dowling, E., Nunes, R., \& Trott, B. (2007). Immaterial and affective labour: Explored. Ephemera: Theory and Politics in Organization, 7(1), 1-7.

Estopace, D. (2013). From sunrise to 'eternal sunshine' industry. http://www.businessmirror. com.ph/index.php/en/features/perspective/15226-from-sunrise-to-eternal-sunshine-industry. Accessed 30 Nov 2013.

Fabunan, S. S. D. (2013). Palace warns vs cyber sex.http://manilastandardtoday.com/2013/11/08/ palace-warns-vs-cyber-sex/. Accessed 30 Nov 2013.

GMA News. (2013a). Manila and Cebu in top 10 global outsourcing destinations. http://www. gmanetwork.com/news/story/292785/economy/business/manila-and-cebu-in-top-10-globaloutsourcing-destinations. Accessed 30 Nov 2013.

GMA News. (2013b). Abad: Gov't will help booming BPO industry. http://www.gmanetwork.com/ news/story/300947/economy/business/abad-gov-t-will-help-booming-bpo-industry. Accessed 30 Nov 2013.

GMA News. (2013c). BPO revenues rose $18 \%$ in 2012 - IBPAP. http://www.gmanetwork.com/ news/story/298940/economy/business/bpo-revenues-rose-18-in-2012-ibpap. Accessed 30 Nov 2013.

Gonzalez, V., \& Rodriguez, R. M. (2003). Filipina.com: Wives, workers and whores on the cyberfrontier. In R. C. Lee \& S. L. C. Wong (Eds.), Asian America.Net: Ethnicity, nationalism and cyberspace (pp. 215-234). New York: Routledge.

Hansen, M. (2006). Bodies in code: Interfaces with new media. New York/London: Routledge.

Hardt, M. (1999) Affective labor. Boundary 2, 26(2), 89-100. http://www.jequ.org/files/affectivelabor.pdf. Accessed 30 Nov 2013.

Hardt, M., \& Negri, A. (2000). Empire. Cambridge, MA: Harvard University Press.

Hardt, M., \& Negri, A. (2004). Multitude. New York: Penguin Press.

Hayles, N. K. (1999). How we became posthuman: Virtual bodies in cybernetics, literature, and informatics. Chicago: The University of Chicago Press.

Jacobs, K. (2007). Netporn: DIY web culture and sexual politics. Lanham: Rowman \& Littlefield.

Lazzarato, M. (1996). Immaterial labour. In P. Virno \& M. Hardt (Eds.), Radical thought in Italy: A potential politics (pp. 132-146). Minneapolis: University of Minnesota Press.

Lopez, R. (2013). Virtual Filipina kid lures 1,000 'sexual predators' worldwide. http://www.mb. com.ph/virtual-filipina-kid-lures-1000-sexual-predators-worldwide/. Accessed 30 Nov 2013.

Massumi, B. (2002). Parables for the virtual: Movement, affect, sensation. Durham/London: Duke University Press.

Mirchandani, K. (2012). Phone Clones: Authenticity Work in the Transnational Service Economy. Ithaca, NY: Cornell University Press.

Nagel, J. (2003). Race, ethnicity and sexuality: Intimate intersections, forbidden frontiers. New York: Oxford University Press.

National Economic and Development Authority. (2011). Philippine development plan (20112016). http://www.neda.gov.ph/PDP/2011-2016/frontmatter.pdf. Accessed 30 Nov 2013.

National Statistical Coordination Board. (2012). Statistical indicators on Philippine development (Chapter/sector: Competitive industry and services sectors). http://www.nscb.gov.ph/stats/ statdev/2012/ch2_industry.asp. Accessed 30 Nov 2013.

National Statistical Coordination Board. (2013). Philippine statistics in brief. http://www.nscb.gov. ph/download/NSCB_PhilippinesInBrief_Apr2013.pdf. Accessed 30 Nov 2013.

Negri, A., \& Hardt, M. (1999). Value and affect. Boundary 2, 26(2), 77-88.

Paasonen, S. (2011). Carnal resonance: Affect and online pornography. Cambridge, MA: MIT Press.

Philippine Digital Strategy. (2010). http://icto.dost.gov.ph/index.php/philippine-digital-strategy. Accessed 30 Nov 2013.

Quigley, J. T. (2013). Virtual 10-year-old Filipina reveals thousands of cybersex predators. http://thediplomat.com/2013/11/virtual-10-year-old-filipina-reveals-thousands-of-cyberpredators/. Accessed 30 Nov 2013. 
Remo, M. V. (2013). NSCB says PH Internet penetration rate at $36 \%$. http://technology.inquirer. net/30571/nscb-says-ph-internet-penetration-rate-up-36. Accessed 30 Nov 2013.

Robins, K., \& Webster, F. (1988). Cybernetic capitalism: Information, technology, everyday life. In V. Mosco \& J. Wasko (Eds.), The political economy of information (pp. 44-75). Madison: University of Wisconsin Press.

Romero, P. (2013). SC extends TRO on cybercrime law. http://www.rappler.com/nation/21089-scextends-tro-on-cybercrime-law. Accessed 30 Nov 2013.

Sabangan, A. R. C. (2003). In the chatrooms: A look into the minds of cybersex addicts. Manila Times. http://trafficking.org.ph/v5/index.php?option=com_content\&task= view\&id=407\&Itemid=56. Accessed 30 Nov 2013.

Saloma-Akpedonu, C. (2006). Possible worlds in impossible spaces: Knowledge, globality, gender, and information technology in the Philippines. Quezon City: Ateneo de Manila University Press.

Seigworth, G. J., \& Gregg, M. (2010). An inventory of shimmers. In The affect theory reader (pp. 1-25). Durham y Londres: Duke University Press.

Tadiar, N. X. M. (2004). Fantasy-production: Sexual economies and other Philippine consequences for the new world order. Hong Kong: Hong Kong University Press.

Tadiar, N.X.M. (2009). If not mere metaphor, sexual economies reconsidered. The scholar and feminist online. http://sfonline.barnard.edu/sexecon/tadiar_01.htm. Accessed 21 Nov 2014.

The Vincenton Post. (2009). Special report: Cybersex trade thrives in a time of crisis. http://fvdb. wordpress.com/2009/11/10/cybersex-trade-thrives-in-time-of-crisis/. Accessed 30 Nov 2013.

Weitzer, R. (2010). The mythology of prostitution: Advocacy research and public policy. Sexuality Research and Social Policy, 7(1), 15-29. 